\title{
Presidential Election Campaigns and American Democracy
}
American Behavioral Scientist Volume 49 Number 1 September 2005 48-62 (C) 2005 Sage Publications $10.1177 / 0002764205279429$ http://abs.sagepub.com hosted at http://online.sagepub.com

\section{The Relationship Between Communication Use and Normative Outcomes}

\author{
Michael Pfau \\ J. Brian Houston \\ Shane M. Semmler \\ University of Oklahoma
}

\begin{abstract}
There is very little research about the relative influence of campaign communication forms or venues on normative outcomes concerning the extent to which campaign communication promotes or degrades basic democratic values. This investigation assesses the relative impact of 17 communication forms on three normative outcomes: political expertise, which embodies people's awareness, knowledge, and interest in politics; attitude about the process used to elect candidates; and likelihood of participating in the political process. Data are based on results of two national surveys conducted in different phases of the 2004 presidential campaign. Hierarchical regression analyses are used to evaluate the relative influence of the 17 communication forms on normative outcomes, controlling for sociodemographic variables.
\end{abstract}

Keywords: media use; democracy

The relationship between media use and civic and political behavior is complicated and only partly understood.

—Michael Delli Carpini (2004, p. 418)

Recent research examines the relative impact of various communication forms or venues (e.g., newspapers, the Internet, network television news) on users' perceptions of political candidates and likelihood of voting for them. However, little attention has been paid to the relative impact of these forms on normative outcomes. Such reticence must end because, as McLeod, Kosicki, and McLeod (1994) insisted, political communication research "cannot evade normative assumptions of how social institutions 'ought to' work” (p. 123).

Authors'Note: The authors thank Dr. Mary Outwater of the University of Oklahoma Public Opinion Learning Laboratory for administering the surveys featured in this manuscript. 
Normative questions address core democratic values. In the context of American election campaigns, normative issues focus on how campaigns should work. For example, normative issues concern whether campaign communication contributes to positive attitudes about the process used to elect candidates, facilitates people's involvement in politics, and enhances likelihood of participating in the political process. Normative questions are among the most important campaign communication effects. Campaign practices, and campaign communication in particular, "matter to the practice of democracy" (Geer \& Lau, 1998, p. 1), not just because they affect electoral choice that "affects the course of government" (Geer \& Lau, 1998, p. 1) but also because they leave an indelible imprint on the process of democracy.

For better or worse, today "the mass media are the public sphere" (Carpignano, Andersen, Aronowitz, \& DiFazio, 1993, p. 93), but the mass media embody many diverse communication forms. The question is, Which communication forms promote, and which degrade, normative outcomes? In an era in which analysts warn of rising levels of public cynicism and Americans' disengagement in public life (e.g., Moy \& Pfau, 2000; Nye, Zelikow, \& King, 1997; Putnam, 2000), communication venues employed in campaigns may ameliorate or exacerbate these problems. Blumler and Gurevitch (1995) are among the gloomsters; they have charged that today's dominant political communication venues are more apt "to strain against, rather than with, the grain of citizenship" (p. 203). However, there is a paucity of empirical evidence about this claim, and that which is available is divided as to whether communication forms exert a positive or negative impact.

The limited research addressing this question tends to employ one of two approaches. The first strategy is macro in nature, examining the overall impact of television use on normative outcomes. Putnam's (2000) research embodies this approach. Putnam concluded that greater television use, in general, is associated with reductions in "virtually every form of civic participation and social involvement" (p. 228), the only exception being the small proportion who view television mainly for information. In much the same vein, Shah, Kwak, and Holbert (2001) revealed that people's use of television for diversionary purposes undermines political involvement, whereas their use for informational purposes enhances involvement. Finally, Brehm and Rahn (1997) found that television use reduces civic involvement, possibly because of simple time displacement.

However, Norris (2002) disputed these findings, especially during election campaigns. Her examination of National Election Study data from the 2000 presidential campaign indicates that people who watch television, whether they view news content or a mix of news and entertainment fare, "are ... relatively high in civic engagement." Norris concluded, "It appears that a mixed diet of television does no harm" (p. 8). Norris's multiple regression analyses indicate that although heavy exposure to campaign advertisements and television entertainment fare result in some negative outcomes, "these findings are outweighed by the number of cases where exposure to campaign information from different sources is positively related to indicators of civic engagement" (p. 8), operationalized in terms of knowledge, trust, efficacy, political discussion, and turnout. 
A second strategy employs more of a micro approach to the influence of communication forms on normative outcomes: either analyzing communication forms individually, in isolation from all other forms, or comparing the impact of two communication forms, usually newspapers and television news.

Television news is the focus of many of these studies. Some have argued that the nature of television news - the frames employed (Cappella \& Jamieson, 1997), the "horse race" fixation in most campaign reporting (Patterson, 1993), or the hostile tone of television news reports (Robinson, 1975, 1976, 1977) —undermines normative outcomes. Some media-use studies support this position. For example, McLeod, Scheufele, and Moy (1999) found that people's use of newspapers, but not television news, enhanced political participation. Eveland and Scheufele (2000) revealed a similar finding but reported that this effect is most pronounced among more educated respondents. As Eveland and Scheufele explained,

Rather than providing information that is potentially useful in mobilizing a broad cross section of citizens during campaigns, newspapers seem to provide information that disproportionately benefits individuals who are already more likely to engage in participatory activities, the more educated strata of society. (p. 231)

However, other studies indicate that television news use relates positively to normative outcomes, particularly to electoral participation (e.g., Bucy, D'Angelo, \& Newhagen, 1999; McLeod et al., 1996; Norris, 2002; Wilkins, 2000).

Some research indicates that attack-oriented political advertisements suppress turnout (Ansolabehere \& Iyengar, 1995; Ansolabehere, Iyengar, Simon, \& Valentino, 1994; Kahn \& Kenney, 1999), although meta-analyses dispute demobilization claims (e.g., Finkel \& Geer, 1998; Lau \& Pomper, 2004; Lau \& Sigelman, 2000), whereas one study suggests that negative advertisements stimulate voter turnout (Goldstein \& Freedman, 2002). Research indicates that debate viewing enhances political participation (Hart, 2000; Patterson, 2002; Pfau, 2002; The Racine Group, 2002), although two studies of the 1996 debates found for the null (Spiker \& McKinney, 1999; Weaver, Drew, \& Wu, 1998), thus reinforcing the position of Hellweg, Pfau, and Brydon (1992) that the campaign context (e.g., whether the presidential election appears closely contested) dictates the potential for all debate effects, whether they concern influence or normative questions. Research indicates that despite the negativity of political talk radio, which fuels cynicism about democratic institutions (Moy \& Pfau, 2000), people's use of political talk radio is related to various indices of political participation (Bennett, 1998; Hofstetter et al., 1994; Owen, 1996; Pan \& Kosicki, 1997). Also, a study by Mutz (2004) finds that "hostile" television political talk shows such as Hardball exert "a negative impact on how viewers feel about politicians in general and the whole political system" (p. 1), suggesting the potential for demobilizing effects. Finally, studies by Davis (1999) and Norris (2001) indicate that although Internet political use engages partisan activists, it exerts limited impact on overall political participation. 
Other research simultaneously examines people's use of more than two communication forms, including use of "new media." Bucy et al. (1999) found that use of radio and television talk shows is associated with greater political interest, which serves as "a proxy for civic involvement" (p. 347). Davis and Owen (1998) indicated that use of political talk radio and television news magazines were related to greater interest in presidential campaigns. Studies of Internet use and political interest produce equivocal results: Davis and Owen indicated no relationship, but Johnson and Kaye (1998) reported a positive association.

This study takes a third approach. It examines the relative influence of all relevant communication forms: traditional news venues, talk shows, entertainment fare, the Internet, political conversations, and so forth. It expands on the findings of Pfau, Cho, and Chong (2001), who found that in the 2000 presidential campaign, people's use of newspapers and televised presidential debates and their political conversations facilitated most normative outcomes (knowledge of the candidates and their positions, interest in the campaign, and participation), whereas people's use of television network news and radio news enhanced at least one outcome. By contrast, use of news magazines, print materials (yard signs, mailers, etc.), campaign advertisements, political talk radio, television news magazines, television talk shows, and the Internet exerted no influence on normative outcomes. Based on a synthesis of past research, this investigation anticipated that use of newspapers, televised debates, and political conversations would contribute most to normative outcomes; use of television network news and radio news would contribute somewhat less; use of political talk radio would produce mixed outcomes; and use of pure entertainment forms (e.g., movies/ DVDs, television comedic programming) would undermine normative outcomes.

This study operates on the premise that "we should look at what all the media have to say," systematically examining "the totality of political information that is made available" to citizens (Page, 1996, p. 7). Delli Carpini (2004) justified this more comprehensive media approach, arguing that

politically relevant information can take many forms ..., emanate from many sources (from face-to-face exchanges to newspapers to television to the Internet), and have many different impacts. ... Beginning with the questions, "What information matters?" and "Where do people get this information?" and letting the answers to these questions determine the particular media and genres we study, would, I believe, produce a more nuanced, integrated, and ultimately accurate picture of how media affects democratic engagement. (p. 423)

\section{Method}

The study assesses the relative impact of 17 communication forms on normative outcomes during two periods of the 2004 presidential campaign: the first in September (from September 9, following the Republican National Convention, through the afternoon of September 30, on the eve of the first presidential debate); and the second dur- 
ing the final 2 weeks of the general election campaign (from October 18 through November 1).

\section{Survey Method}

Two national surveys were conducted by the University of Oklahoma Public Opinion Learning Laboratory. The first survey consisted of 467 partially completed interviews (406 fully completed interviews), and the second survey consisted of 458 partially completed interviews (402 fully completed interviews). All respondents were prospective voters who resided in the 48 contiguous states. The sample was obtained from Survey Sampling Inc. and was screened of nonresidential numbers. The survey instrument was pilot tested before actual fieldwork.

The margin of error for the first survey was $+/-4.52 \%$ at a $95 \%$ confidence level; the response rate was $33.9 \%$. The margin of error for the second survey was $+/-4.56 \%$ at a $95 \%$ confidence level and the response rate was $39.8 \%$. Samples were reasonably representative of the populations from which they were drawn. ${ }^{1}$

The surveys gathered relevant sociodemographic data, probed communication use patterns during the 2004 presidential election campaign, and assessed respondents' perceptions reflecting basic democratic values (e.g., attitudes toward the process by which a president is elected, political expertise, and participation).

\section{Variables and Instruments}

Respondent sociodemographics, including sex, age, education, household income, and political party affiliation, functioned as control variables in all analyses; political expertise served as a dependent variable in one analysis and as a control variable in two analyses.

Respondent sex was determined without specifically asking and was operationalized as male or female. Age was assessed by asking respondents to indicate their age on their last birthday as younger than 30,30 to 44, 45 to 59, or 60 or older. Education was operationalized as some high school, high school degree, some post-high school education, college or professional school degree, or a master's or advanced professional degree. Household income was operationalized as less than US $\$ 15,000$; from US $\$ 15,000$ to US $\$ 29,999$; from US $\$ 30,000$ to US $\$ 44,999$; from US $\$ 45,000$ to US\$59,999; from US\$60,000 to US\$74,999; and more than US\$75,000. Respondent political party affiliation was gauged as Democrat, Republican, Independent, or no affiliation. Prior to data analyses, dummy variables for Democratic and Republican affiliation were computed from the party identification variables. Political expertise was operationalized as respondents' awareness of, interest in, and knowledge of the presidential campaign. It was assessed using three 7-interval, bipolar scales employed in past research by Fiske, Lau, and Smith (1990), Price and Zaller (1993), and Moy and Pfau (2000). Cronbach's alpha reliability ratings of the political expertise were, for Survey 1, .87 $(N=406)$, and for Survey 2, $.87(N=403)$. 
Communication use was the independent variable of interest in this study. The study features multiple communication sources, reflecting the "transformational" nature of contemporary use patterns (Chesebro \& Bertelsen, 1996, p. 134). Scholars have justified this more comprehensive approach to media use. For example, Moy and Pfau (2000) argued that "today's media environment embodies a complex mosaic of communication sources" (p. 65). Holbert (2004) advised that "no one type of media content functions in a vacuum relative to other media" (p. 645). The implication of this position is that researchers should examine the entire array of communication forms in tandem, which enables a parsing of the influence of any one form while simultaneously controlling for the influence of all other forms.

This study operationalized communication use as exposure to a particular communication form, and the attention paid to the communication form, as a source of information about presidential candidates or the presidential campaign. Respondents' exposure to and attention paid to communication forms were each assessed with 7interval Likert-type scales based on measures used previously by Chaffee and Schleuder (1986) and McLeod and McDonald (1985).

The combined approach, especially with studies that seek to compare different media, is highly recommended. As Chaffee and Schleuder (1986) explained, "If . . . one anticipates making comparisons between media, ... then media attention measures are essential" (pp. 103-104).

The communication forms included in the investigation and any exemplars featured in the survey instrument, plus Cronbach's alpha reliability ratings (computed on the summed exposure and attention measures) were as follows: ${ }^{2}$ newspapers, Survey 1, .82, Survey 2, .83; news magazines (e.g., Time), Survey 1, .77, Survey 2, .79; network television news, Survey 1, .73, Survey 2, .78; local television news, Survey 1 and Survey 2, .81; political talk radio, Survey 1, .77, Survey 2, .83; radio news, Survey 1, .75, Survey 2, .79; television talk shows (e.g., Larry King Live or Hardball), Survey 1, .78 , Survey 2, .77; television entertainment talk shows (e.g., Leno or Letterman), Survey 1, .76, Survey 2, .79; prime-time television political drama (e.g., The West Wing), Survey 1, .76, Survey 2, .70; television comedy (e.g., Saturday Night Live), Survey 1, .68, Survey 2, .77; television news magazines (e.g., 60 Minutes or 20/20), Survey 1, .77, Survey 2, .84; movies or DVDs (e.g., Fahrenheit 9/11), Survey 1, .79, Survey 2, .77; the World Wide Web, Survey 1 and Survey 2, .85; televised candidate debates, Survey $1, .85$, Survey $2, .90$; televised candidate advertisements, Survey $1, .69$, Survey 2, .73; conversations with others, Survey 1, .79, Survey 2, .86; and print materials (e.g., direct mail, flyers), Survey 1, .71, Survey $2, .73$.

The study features three dependent variables (political expertise served as a dependent variable for one analysis and as a control variable on two analyses; it was described previously).

Attitude toward the process by which a president is elected was assessed using six 7-interval bipolar adjective pairs developed by Burgoon, Cohen, Miller, and Montgomery (1978). This attitude measure has attained excellent reliabilities in past political communication research. The adjective opposite pairs include foolish/wise, 
unacceptable/acceptable, negative/positive, wrong/right, unfavorable/favorable, and bad/good. Cronbach's alpha reliability of the attitude toward process scale in the first survey was .92 $(N=407)$ and in the second survey was .96 $(N=405)$.

Three behavioral disposition items were employed to assess likelihood of participating in the political process. Respondents were asked, on a scale from 0 to 100 , where $0=$ no chance and $100=$ near certain probability, what is the likelihood that they would: "actively seek information about the presidential candidates and/or their positions," "contribute either time or money to a presidential political campaign," and "go to the polls and vote on November 2." The participation items were summed. Reliability ratings were $.63(N=407)$ in the first survey and $.65(N=405)$ in the second survey.

\section{Analytic Procedures}

Hierarchical regression analyses were employed to assess the relative influence of communication forms on normative outcomes. The variables were entered causally: sociodemographic variables in Block 1 and communication forms in Block 2. This method permitted a judgment of the influence of each block of variables on normative outcomes and ensured a net judgment of communication effects, assessed after controlling for other influences.

\section{Results}

\section{The Mid- and Late September Phase of the Campaign}

The results of the first survey, conducted during mid- and late September, reveal that the full regression equations were significant for all dependent variables: political expertise, $F(23,381)=13.19, p<.001$; attitude toward the process used to elect a president, $F(24,380)=2.87, p<.001$; and likelihood of participating in the political process, $F(24,380)=13.69, p<.001$.

As Table 1 reveals, a number of sociodemographic variables significantly affected normative outcomes. Respondents' gender affected political expertise and displayed a negative beta, thus, indicating that males manifested greater expertise. Democratic and Republican Party identification positively affected political expertise, Democratic Party identification positively influenced attitude toward process (Republican Party identification fell just short of significance), and Democratic and Republican Party identification bordered on statistical significance on likelihood of participating. In all cases, respondents' party identification was positively associated with normative outcomes. Respondents' education level positively influenced both political expertise and likelihood of participating, and political expertise, in turn, positively affected both attitude toward process and the likelihood of participating.

The results indicate that during mid- and late September, people's political conversations and anticipation of impending debates were positively associated with politi- 
Table 1

Mid/Late September Media Use and Attitudes About Democratic Process

\begin{tabular}{|c|c|c|c|}
\hline & $\begin{array}{c}\text { Attitude Toward } \\
\text { Process }\end{array}$ & $\begin{array}{l}\text { Political } \\
\text { Expertise }\end{array}$ & $\begin{array}{r}\text { Likelihood of } \\
\text { Participating }\end{array}$ \\
\hline \multicolumn{4}{|l|}{ Control variables } \\
\hline Gender (male) & .08 & $-.11 * * *$ & .015 \\
\hline Age & .03 & $.19 * * *$ & $-.08 *$ \\
\hline Education & $-.11+$ & $.17 * * *$ & $.09 * *$ \\
\hline Income & $-.10^{*}$ & .045 & .07 \\
\hline Party ID (Democrat) & $-.12 * *$ & $.10 * *$ & $.08 *$ \\
\hline Party ID (Republican) & $.11^{*}$ & $.17 * * *$ & $.09 *$ \\
\hline Political expertise & $.15^{* *}$ & - & $.42 * * *$ \\
\hline$R^{2}$ & $.105 * * *$ & $.21 * * *$ & $.38 * * *$ \\
\hline \multicolumn{4}{|l|}{ Communication use } \\
\hline Network TV news & -.095 & .04 & .01 \\
\hline Local TV news & .10 & $.11 * *$ & -.02 \\
\hline Newspapers & $-.11 * *$ & -.025 & .00 \\
\hline Magazines & .00 & .02 & .01 \\
\hline Political talk radio & .01 & $.11 * *$ & -.03 \\
\hline Radio news & .04 & -.06 & .08 \\
\hline TV talk & -.02 & $.11 * *$ & -.06 \\
\hline TV entertainment talk shows & -.02 & .07 & -.01 \\
\hline TV political drama & -.08 & -.05 & -.06 \\
\hline TV comedic shows & -.05 & $-.16^{* * *}$ & -.03 \\
\hline TV news magazines & .01 & .04 & -.06 \\
\hline Movies/DVDs & $.13^{* *}$ & .03 & .00 \\
\hline World Wide Web & -.01 & .01 & .06 \\
\hline Candidate debates & .07 & $.24 * * *$ & $.14 * * *$ \\
\hline Candidate ads & -.045 & -.08 & -.03 \\
\hline Conversations & $.09 *$ & $.24 * * *$ & $.19 * * *$ \\
\hline Printed materials & $.09 *$ & .05 & $-.09 *$ \\
\hline Incremental $R^{2}$ & .05 & $.24 * * *$ & $.08 * * *$ \\
\hline Model $F(24,380)=$ & $2.87 * * *$ & $13.19 * * *$ & $13.69 * * *$ \\
\hline
\end{tabular}

Note: Entries are standardized coefficients from OLS regression.

$* p<.10 . * * p<.05$. *** $p<.01$.

cal expertise and likelihood of participating. Other communication forms affected one of the three normative indicators during this phase of the presidential campaign. People's use of newspapers negatively, and use of movies/DVDs positively, influenced their attitudes toward process. In addition, use of local television news, political talk radio, and television entertainment talk shows positively, and television comedic programs negatively, affected political expertise. Most communication forms exerted no impact on either attitude toward process or likelihood of participating. Overall variances accounted for by combined communication forms on normative indicators were modest: $24 \%$ for political expertise and with expertise incorporated into analyses as a control variable, $5 \%$ on attitude toward process, and $8 \%$ on the likelihood of participating. 


\section{The Concluding Phase of the Campaign}

The results of the second survey, conducted during the final 2 weeks of the 2004 campaign, indicate that full regression equations were significant for all three dependent variables: political expertise, $F(23,378)=8.33, p<.001$; attitude toward the process used to elect a president, $F(24,377)=4.54, p<.001$; and likelihood of participating in the political process, $F(24,377)=13.97, p<.001$.

Sociodemographic variables exerted somewhat less impact on normative outcomes and communication variables exerted somewhat greater influence than in September. As Table 2 illustrates, no sociodemographic variables affected political expertise, although respondents' gender (with a negative beta, indicating that males manifested somewhat greater expertise), age, and education level (the latter two with positive betas) all approached statistical significance. However, political expertise positively affected both attitude toward process and likelihood of participating.

Republican, but not Democratic, identification was positively related to attitude toward process; Democratic identification, but not Republican, was positively related to the likelihood of participating. Finally, respondents' gender and education were positively, and age was negatively, associated with likelihood of participating.

Communication effects were more robust in late October, both in the number of communication forms affecting normative outcomes and in the overall variance accounted for by communication forms: $29 \%$ on political expertise, $9 \%$ on attitude toward process, and $12 \%$ on likelihood of participating.

The results indicate that during late October, respondents' use of political talk radio was positively associated with all three normative indices: political expertise, attitude toward process, and likelihood of participating. In addition, reliance on televised debates and people's political conversations were both positively related to political expertise and likelihood of participating.

Most other communication forms were significantly linked to one of the three dependent measures, most positively. Greater use of network television news was positively related to political expertise. More use of television entertainment talk shows was positively associated with attitude toward process, and greater use of newspapers was positively related to the likelihood of participating.

Some communication forms exerted a negative impact on single normative measures. Greater use of radio news and movies/DVDs was negatively related to attitude toward process. More reliance on television comedy was negatively associated with likelihood of participating.

\section{Discussion}

Overall, the pattern of results suggests that the impact of communication on normative outcomes increases as an election nears. This suggests that Barber (2003) may be right that "communication is at the heart of democracy" (p. xiv) in the sense that as Election Day nears, communication increasingly affects people's attitude toward, and involvement and participation in, the political process. 
Table 2

Mid/Late October Media Use and Attitudes About Democratic Process

\begin{tabular}{|c|c|c|c|}
\hline & $\begin{array}{c}\text { Attitude Toward } \\
\text { Process }\end{array}$ & $\begin{array}{l}\text { Political } \\
\text { Expertise }\end{array}$ & $\begin{array}{r}\text { Likelihood of } \\
\text { Participating }\end{array}$ \\
\hline \multicolumn{4}{|l|}{ Control variables } \\
\hline Gender (male) & $.08 *$ & $-.08 *$ & $.10 * *$ \\
\hline Age & -.03 & $.10^{*}$ & $-.11 * *$ \\
\hline Education & $-.09 *$ & $.08 *$ & $.10 * *$ \\
\hline Income & .00 & .04 & .045 \\
\hline Party ID (Democrat) & .015 & .04 & $.13 * * *$ \\
\hline Party ID (Republican) & $.20 * * *$ & .08 & .03 \\
\hline Political expertise & $.20 * * *$ & - & $.33 * * *$ \\
\hline$R^{2}$ & $.14 * * *$ & $.05 * * *$ & $.33 * * *$ \\
\hline \multicolumn{4}{|l|}{ Communication use } \\
\hline Network TV news & .09 & $.14 * *$ & .02 \\
\hline Local TV news & .09 & $-.10 *$ & -.05 \\
\hline Newspapers & .02 & .05 & $.10 * *$ \\
\hline Magazines & -.03 & .055 & -.01 \\
\hline Political talk radio & $.13 * *$ & .03 & $.15 * * *$ \\
\hline Radio news & $-.12 * *$ & $.15 * * *$ & .04 \\
\hline TV talk & -.04 & .01 & .04 \\
\hline TV entertainment talk shows & $.15^{* *}$ & .02 & .05 \\
\hline TV political drama & .07 & .05 & -.01 \\
\hline TV comedic shows & -.04 & -.09 & $-.16 * * *$ \\
\hline TV news magazines & -.08 & -.025 & -.06 \\
\hline Movies/DVDs & $-.17 * * *$ & .05 & .06 \\
\hline World Wide Web & -.01 & .00 & .07 \\
\hline Candidate debates & -.08 & $.32 * * *$ & $.11 * *$ \\
\hline Candidate ads & .07 & .05 & -.04 \\
\hline Conversations & .08 & $.115^{* *}$ & $.24 * * *$ \\
\hline Printed materials & .04 & -.05 & .04 \\
\hline Incremental $R^{2}$ & $.09 * * *$ & $.29 * * *$ & $.14 * * *$ \\
\hline Model $F(24,380)=$ & $4.54 * * *$ & $8.33 * * *$ & $13.97 * * *$ \\
\hline
\end{tabular}

Note: Entries are standardized coefficients from OLS regression.

$* p<.10 . * * p<.05$. *** $p<.01$.

The pattern of results of this study indicates that most of the more traditional communication forms, and some alternative forms, exert positive influence on normative outcomes. Overall, people's reliance on televised debates (early on, anticipation of debates; later, actual viewing of debates), use of political talk radio, and political conversations were significantly associated with multiple normative outcomes across two phases of the general election campaign. These results support previous findings that people's political conversations (Pfau et al., 2001) and their use of televised political debates (Hart, 2000; Patterson, 2002; Pfau, 2002; The Racine Group, 2002) and political talk radio (Bennett, 1998; Bucy et al., 1999; Hostetter et al., 1994; Owen, 1996; Pan \& Kosicki, 1997) foster normative outcomes. 
Other traditional communication forms exerted more limited influence on normative outcomes. In September, local television news, and during late October, network television news, were positively related to political expertise. Also during October, use of newspapers was positively associated with likelihood of participating. Among traditional communication forms, only use of radio news was negatively linked to normative outcomes, and only on one measure: In late October, it was negatively associated with attitude toward process. This pattern of results suggests that these traditional communication venues promote normative outcomes, confirming past findings of Norris (2002), Bucy et al. (1999), McLeod et al. (1996), and Pfau et al. (2001).

By contrast, more entertainment-oriented communication forms exerted mixed influence on normative outcomes. People's use of television comedic programs was most corrosive. During September, it was negatively associated with political expertise and in late October it was negatively related to likelihood of participating. However, the influence of television entertainment talk shows (e.g., Leno and Letterman) was positive. During September, it was positively associated with political expertise; in late October, it was positively associated with attitude toward process. The influence of movies/DVDs was mixed. People's use of movies/DVDs was positively associated with attitude toward process earlier in the campaign but negatively related to attitude toward process late in the campaign.

Other communication forms exerted no influence on normative outcomes, either early or late in the 2004 presidential election campaign. People's use of news magazines, television talk shows, prime-time television political drama, television news magazines, the World Wide Web, televised candidate advertising, and printed materials affected no normative outcomes. The null results for the Internet contradicts some research indicating that Internet use promotes political interest (Johnson \& Kaye, 1998), but they are consistent with most previous studies examining Internet use and political interest and/or participation (e.g., Davis, 1999; Davis \& Owen, 1998; Norris, 2001; Pfau et al., 2001). Despite the uproar concerning whether political attack advertisements stimulate, suppress, or have no effect on turnout, this is the second consecutive study that examines people's use of advertisements in tandem with other relevant communication forms and reports no effects at all on normative outcomes (Pfau et al., 2001). Of course, all research that asks respondents to self-report their exposure and attention paid to communication probably underreports political advertisement use. People are particularly hesitant to acknowledge use of political advertisements, which they claim to dislike more than other political communication forms.

\section{Conclusion}

Today, the "mass media are the public sphere" (Carpignano et al., 1993, p. 93), but mass media includes many diverse venues, which precludes broad generalizations about the mass media and democracy. "We should look at what all the media have to say" (Page, 1996, p. 7) because "politically-relevant information can take many forms . . . , emanate from many sources, ... and have many different impacts" (Delli 
Carpini, 2004, p. 423). The pattern of results of this study, it is hoped, contributes to "a more nuanced, integrated, and ultimately accurate picture of how media affects democratic engagement" (Delli Carpini, 2004, p. 423).

\section{Notes}

1. Sample demographics included the following: for gender, Survey 1, 63.5\% female, $36.5 \%$ male, Survey $2,60.9 \%$ female, $39.1 \%$ male; for age, Survey $1,16 \%$ younger than 30 years old, $23.9 \% 30$ to 44 years old, $30.8 \% 45$ to 59 years old, and $29.3 \% 60$ years or older, Survey $2,15.9 \%$ younger than 30 years old, $23.6 \% 30$ to 44 years old, $36.1 \% 45$ to 59 years old, and $24.4 \% 60$ years or older; for years of school completed, Survey 1, 4.4\% some high school, $23.2 \%$ high school degree, $26.4 \%$ some post-high school education, $29.1 \%$ college degree, $16.5 \%$ master's or advanced professional degree, and $0.5 \%$ refused, Survey 2 , $4.0 \%$ some high school, $22.9 \%$ high school degree, $27.1 \%$ some post-high school education, $28.1 \%$ college degree, $16.7 \%$ master's or advanced professional degree, and $1.2 \%$ refused; for party identification, Survey 1,27.3\% Democrat, 37.7\% Republican, $16.0 \%$ Independent, $17.7 \%$ no affiliation, and $1.2 \%$ refused, Survey 2, 29.6\% Democrat, $35.8 \%$ Republican, $15.2 \%$ Independent, $18.2 \%$ no affiliation, and $1.2 \%$ refused; and for income, Survey $1,6.4 \%$ less than US $\$ 15,000,12.8 \%$ between US $\$ 15,000$ and US $\$ 29,999,16.3 \%$ between US $\$ 30,000$ and US $\$ 44,999,12.6 \%$ between US $\$ 45,000$ and US $\$ 59,999,10.8 \%$ between US $\$ 60,000$ and US $\$ 74,999,30.3 \%$ more than US $\$ 75,000$, and $10.8 \%$ refused, Survey $2,4.0 \%$ less than US $\$ 15,000,14.9 \%$ between US $\$ 15,000$ and US $\$ 29,999,16.2 \%$ between US $\$ 30,000$ and US $\$ 44,999,13.2 \%$ between US $\$ 45,000$ and US $\$ 59,999,11.2 \%$ between US\$60,000 and US $\$ 74,999,28.4 \%$ more than US $\$ 75,000$, and $12.2 \%$ refused.

2. Communication form reliability ratings were computed based on an $N$ of 467 in the first survey and an $N$ of 458 in the second survey.

\section{References}

Ansolabehere, S., \& Iyengar, S. (1995). Going negative: How political advertisements shrink and polarize the electorate. New York: Free Press.

Ansolabehere, S., Iyengar, S., Simon, A., \& Valentino, N. (1994). Does attack advertising demobilize the electorate? American Political Science Review, 88, 829-838.

Barber, B. R. (2003). Strong democracy: Participatory politics for a new age (20th anniversary ed.). Berkeley: University of California Press.

Bennett, S. E. (1998). Political talk radio shows' impact on democratic citizenship. In T. J. Johnson, C. E. Hays, \& S. P. Hays (Eds.), Engaging the public: How government and media can reinvigorate American democracy (pp. 111-122). New York: Rowman \& Littlefield.

Blumler, J. G., \& Gurevitch, M. (1995). The crisis of public communication. New York: Routledge.

Brehm, J., \& Rahn, W. (1997). Individual-level evidence for the causes and consequences of social capital. American Journal of Political Science, 41, 999-1023.

Bucy, E. P., D'Angelo, P., \& Newhagen, J. E. (1999). The engaged electorate: New media use as political participation. In L. L. Kaid \& D. G. Bystrom (Eds.), The electronic election: Perspectives on the 1996 campaign communication (pp. 335-347). Mahwah, NJ: Lawrence Erlbaum.

Burgoon, M., Cohen, M., Miller, M. D., \& Montgomery, C. L. (1978). An empirical test of resistance to persuasion. Human Communication Research, 5, 27-39.

Cappella, J. N., \& Jamieson, K. H. (1997). Spiral of cynicism: The press and the public good. New York: Oxford University Press.

Carpignano, P., Andersen, R., Aronowitz, S., \& DiFazio, W. (1993). Chatter in the age of electronic reproduction: Talk television and the public mind. In B. Robbins (Ed.), The phantom public sphere (pp. 93120). Minneapolis: University of Minnesota Press. 
Chaffee, S. H., \& Schleuder, J. (1986). Measurement and effects of attention to media news. Human Communication Research, 13, 76-107.

Chesebro, J. W., \& Bertelsen, D. A. (1996). Analyzing media: Communication technologies as symbolic and cognitive systems. New York: Guilford.

Davis, R. (1999). The web of politics: The Internet's impact on the American political system. New York: Oxford University Press.

Davis, R., \& Owen, D. (1998). New media and American politics. New York: Oxford University Press.

Delli Carpini, M. X. (2004). Mediating democratic engagement: The impact of communications on citizens' involvement in political and civic life. In L. L. Kaid (Ed.), Handbook of political communication research (pp. 395-434). Mahwah, NJ: Lawrence Erlbaum.

Eveland, W. P., Jr., \& Scheufele, D. A. (2000). Connecting news media use with gaps in knowledge and participation. Political Communication, 17, 215-237.

Finkel, S. E., \& Geer, J. G. (1998). A spot check: Casting doubt on the demobilizing effect of attack advertising. American Journal of Political Science, 42, 573-595.

Fiske, S. T., Lau, R. R., \& Smith, R. A. (1990). On the varieties and utilities of political expertise. Social Cognition, 8, 31-48.

Geer, J., \& Lau, R. R. (1998, August). A new way to model campaign effects. Paper presented at the annual meeting of the American Political Science Association, Boston.

Goldstein, K., \& Freedman, P. (2002). Campaign advertising and voter turnout: New evidence for a stimulation effect. Journal of Politics, 64, 721-740.

Hart, R. A. (2000). Campaign talk: Why elections are goodfor us. Princeton, NJ: Princeton University Press.

Hellweg, S. A., Pfau, M., \& Brydon, S. R. (1992). Televised presidential debates: Advocacy in contemporary America. New York: Praeger.

Hofstetter, C. R., Donovan, M. C., Klauber, M. R., Cole, A., Huie, C. J., \& Yuasa, T. (1994). Political talk radio: A stereotype reconsidered. Political Research Quarterly, 47, 467-479.

Holbert, R. L. (2004). Review of M. A. Baum, "Soft news goes to war," and D. K. Kishnan \& D. Freedman (Eds.), "War and the media." Public Opinion Quarterly, 68, 644-648.

Johnson, T. J., \& Kaye, B. K. (1998). A vehicle for engagement or a haven for the disaffected? Internet use, political alienation and voter participation. In T. J. Johnson, C. E. Hays, \& S. P. Hays (Eds.), Engaging the public: How government and media can reinvigorate American democracy (pp. 123-135). New York: Rowman \& Littlefield.

Kahn, K. F., \& Kenney, P. J. (1999). Do negative campaigns mobilize or suppress turnout? Clarifying the relationship between negativity and participation. American Political Science Review, 93, 877-889.

Lau, R. R., \& Pomper, G. M. (2004). Negative campaigning: An analysis of U.S. Senate elections. Lanham, MD: Rowman \& Littlefield.

Lau, R. R., \& Sigelman, L. (2000). Effectiveness of negative political advertising. In J. A. Thurber, C. J. Nelson, \& D. A. Dulio (Eds.), Crowded airwaves: Campaign advertising in elections (pp. 10-43). Washington, DC: Brookings Institution.

McLeod, J. M., Guo, Z., Daily, K., Steele, C. A., Huang, H., Howowitz, E., et al. (1996). The impact of traditional and nontraditional media forms in the 1992 presidential election. Journalism and Mass Communication Quarterly, 73, 401-416.

McLeod, J. M., Kosicki, G. M., \& McLeod, D. M. (1994). The expanding boundaries of political communication effects. In J. Bryant \& D. Zillmann (Eds.), Media effects: Advances in theory and research (pp. 123-162). Hillsdale, NJ: Lawrence Erlbaum.

McLeod, J. M., \& McDonald, D. G. (1985). Beyond simple exposure: Media orientations and their impact on political processes. Communication Research, 12, 3-33.

McLeod, J. M., Scheufele, D. A., \& Moy, P. (1999). Community, communication, and participation: The role of mass media and interpersonal discussion in local political participation. Political Communication, 16, 315-336.

Moy, P., \& Pfau, M. (2000). With malice toward all? The media and public confidence in democratic institutions. New York: Praeger.

Mutz, D. (2004). Hostile political TV leads to negative attitudes about politics. Ohio State Research News. Retrieved from http://researchnews.osu.edu/archive/uncivil.htm 
Norris, P. (2001). Digital divide: Civic engagement, information poverty, and the Internet worldwide. Cambridge, UK: Cambridge University Press.

Norris, P. (2002, May). Tuned out voters? Media impact on campaign learning. Paper presented at the Politeia Conference, Brussels, Belgium.

Nye, J. S., Jr., Zelikow, P. D., \& King, D. C. (Eds.). (1997). Why people don't trust government. Cambridge, MA: Harvard University Press.

Owen, D. (1996). Who's talking? Who's listening? The new politics of radio talk shows. In S. C. Craig (Ed.), Broken contract: Changing relationships between Americans and their government (pp. 127-146). Boulder, CO: Westview.

Page, B. I. (1996). Who deliberates? Mass media in modern democracy. Chicago: University of Chicago Press.

Pan, Z., \& Kosicki, G. M. (1997). Talk show exposure as an opinion activity. Political Communication, 14, 371-388.

Patterson, T. E. (1993). Out of order. New York: Knopf.

Patterson, T. E. (2002). The vanishing voter: Public involvement in an age of uncertainty. New York: Knopf.

Pfau, M. (2002). The subtle nature of presidential debate influence. Argumentation and Advocacy, 38, 251261.

Pfau, M., Cho, J., \& Chong, K. (2001). Impact of communication forms in presidential campaigns: Influences on candidate perceptions and democratic process. The Harvard International Journal of Press/ Politics, 6, 88-105.

Price, V., \& Zaller, J. (1993). Who got the news? Alternative measures of news reception and their implications for research. Public Opinion Quarterly, 57, 133-164.

Putnam, R. D. (2000). Bowling alone: The collapse and revival of American community. New York: Simon \& Schuster.

The Racine Group. (2002). White paper on televised political campaign debates. Argumentation and Advocacy, 38, 199-218.

Robinson, M. (1975). American political legitimacy in an era of electronic journalism. In D. Cater \& R. Adler (Eds.), Television as a social force: New approaches to TV criticism (pp. 97-141). New York: Praeger.

Robinson, M. (1976). Public affairs television and the growth of political malaise: The case of "The selling of the Pentagon." American Political Science Review, 70, 409-432.

Robinson, M. (1977). Television and American politics: 1956-1976. Public Interest, 48, 3-39.

Shah, D. V., Kwak, N., \& Holbert, R. L. (2001). "Connecting" and "disconnecting" with civic life: Patterns of Internet use and the production of social capital. Political Communication, 18, 141-162.

Spiker, J. A., \& McKinney, M. S. (1999). Measuring political malaise in the 1996 presidential election. In L. L. Kaid \& D. G. Bystrom (Eds.), The electronic election: Perspectives on the 1996 campaign communication (pp. 319-334). Mahwah, NJ: Lawrence Erlbaum.

Weaver, D., Drew, D., \& Wu, W. (1998). Voter interest and participation in the 1996 presidential election: Did the debates matter? In T. J. Johnson, C. E. Hays, \& S. P. Hays (Eds.), Engaging the public: How government and the media can reinvigorate American democracy (pp. 87-95). Lanham, MD: Rowman \& Littlefield.

Wilkins, K. G. (2000). The role of media in public disengagement from public life. Journal of Broadcasting \& Electronic Media, 44, 569-580.

Michael Pfau (Ph.D., University of Arizona) is a professor and chair of the Department of Communication at the University of Oklahoma. His research interests concern resistance to influence and mass media influence, particularly in a political context. He has coauthored and/or coedited six books, among them Attack Politics: Strategy and Defense (1990, Praeger), Televised Presidential Debates: Advocacy in Contemporary America (2000, Praeger), and The Handbook of Persuasion: Theory and Practice (2002, Sage). He has authored or coauthored more than 100 journal articles and book chapters. 
J. Brian Houston (M.A., University of Oklahoma) is a doctoral student in the Department of Communication at the University of Oklahoma. His research interests include affect and mental representations of knowledge in political and persuasive communication.

Shane M. Semmler (M.A., University of South Dakota) is a doctoral student in the Department of Communication at the University of Oklahoma. His research interests include mass media and interpersonal influence in political communication contexts. 